\title{
ANALISIS RASIO LIKUIDITAS, SOLVABILITAS, DAN RENTABILITAS DALAM LAPORAN KEUANGAN PERUSAHAAN
}

\author{
Tri Wulandari ${ }^{1}$, Hidayat Darwis ${ }^{2}$ \\ ${ }^{1}$ STIE Muhammadiyah Jakarta, tri@ stiemj.ac.id \\ ${ }^{1}$ STIE Muhammadiyah Jakarta, hidayat201161@gmail.com
}

\begin{abstract}
ABSTRAK
Tujuan penelitian ini adalah untuk menganalisa kinerja keuangan perusahaan dengan study kasus pada PT. Marina Berto Tbk. Periode 2012 sampai 2015. Metode penelitian yang digunakan adalah metode deskriptif kausalitas, yaitu menjabarkan kinerja keuangan perusahaan dari aspek rasio likuiditas, rasio solvabilitas dan rasio rentabilitas yang dibandingkan dengan ratio rata-rata industry perusahaan sejenis. Hasil penelitian menunjukkan bahwa secara umum kinerja keuangan PT. Marina berto Tbk berada dibawah rata-rata industry, hal ini berarti belum baik. Walaupun jika dilihat dari current ratio, quick ratio, total asset to debt ratio masih tergolong aman untuk membiayai hutang dan operasional, namun karena terjadi penurunan laba di Tahun 2014 dan 2015 karena cash ratio perusahaan berada dibawah standar. Dan dari segi rasio rentabilitas perusahaan pada tahun tersebut mengalami kesulitan dalam menghasilkan laba karena kosentrasi perusahaan terhadap peningkatan kuantitas produksi dan pengembangan dibidang manufaktur, maka kinerja keuangan menjadi semakin buruk.
\end{abstract}

Kata Kunci: Laporan Keuangan, Rasio Likuiditas, Rasio Solvabilitas, Dan Rasio Rentabilitas

\begin{abstract}
The purpose of this study is to analyze the company's financial performance with a case study at PT. Marina Berto Tbk. The period 2012 to 2015. The research method used is a descriptive causality method, which describes the company's financial performance in terms of liquidity ratios, solvency ratios and profitability ratios compared to the average ratios of similar industry companies. The results showed that in general the financial performance of PT. Marina berto Tbk is below the industry average, which means it's not good. Although when viewed from the current ratio, quick ratio, total assets to debt ratio is still relatively safe to finance debt and operations, but due to a decline in profits in 2014 and 2015 because the company's cash ratio is below standard. And in terms of corporate profitability ratios that year experienced difficulties in generating profits because the company's concentration on increasing the quantity of production and development in manufacturing, then the financial performance was getting worse.
\end{abstract}

Keywords: Financial Statements, Liquidity Ratios, Solvency Ratios, And Profitability Ratios

\section{PENDAHULUAN}

Pasar modal merupakan salah satu sarana untuk mengatasi permasalahan likuiditas perusahaan sekaligus sebagai sarana investasi bagi pihak-pihak yang mempunyai kelebihan dana. Salah satu instrument utama dalam menganalisis kondisi fundamental perusahaan adalah informasi keuangan, Tandelilin (2010:48), Menurut Munawir, (2010:5) "Laporan keuangan itu terdiri dari neraca dan perhitungan laba-rugi serta laporan perubahan ekuitas". Dan menurut Walter, et,al, (2012:2) dalam buku yang berjudul "Akuntansi Keuangan" menyatakan bahwa: 
"Laporan Keuangan (Financial Statements) adalah dokumen bisnis yang digunakan perusahaan untuk melaporkan hasil aktivitasnya kepada berbagai kelompok pemakai yang dapat meliputi manajer, investor, kreditor, dan agen regulator".

Dalam membandingkan angka-angka analisis rasio keuangan, maka diperlukannya data laporan keuangan suatu perusahaan dalam beberapa periode tertentu. Menurut Kasmir (2010:7) menyatakan laporan keuangan adalah laporan yang menunjukkan kondisi keuangan perusahaan pada saat ini atau dalam suatu periode tertentu. Selanjutnya Munawir (2010:5) menjelaskan, laporan keuangan itu terdiri dari neraca dan perhitungan laba-rugi serta laporan perubahan ekuitas. Dan menurut Walter, et,al, (2012:2) menyatakan bahwa laporan keuangan (financial statements) adalah dokumen bisnis yang digunakan perusahaan untuk melaporkan hasil aktivitasnya kepada berbagai kelompok pemakai yang dapat meliputi manajer, investor, kreditor, dan agen regulator. Jadi, dari laporan keuangan perusahaan dapat diperoleh informasi tentang posisi keuangan perusahaan, kinerja perusahaan, aliran kas perusahaan, dan informasi lainnya yang sangat berkaitan dengan laporan keuangan termasuk informasi mengenai laba perusahaan. (Belkoui, 2010:125).

Tujuan dari adanya laporan keuangan adalah untuk menyediakan informasi yang berguna bagi investor dan kreditor untuk memprediksi, membandingkan, dan mengevaluasi aliran kas potensial bagi mereka dalam hal jumlah, waktu, dan ketidakpastian. (Munawir, 2010:7)

Yang terjadi pada PT. Sido Muncul menunjukkan bahwa hasil analisa fundamental saham SIDO 2016 Vs 2015 mata uang yang ada dalam jutaan kecuali saham beredar, EPS, PBV, dll. Aset meningkat $6,85 \%$ dan ekuitas naik $6,14 \%$, perusahaan sedang melakukan pencairan investasi perusahaan dan mengurangi pembelian asset tetap. Perusahaan ini mencatat penjualan saham treasury yang sebelumnya membeli serta membayar dividen. (Krisantus, 2017). Dalam menghindari masalah yang timbul untuk membandingkan perusahaan dengan ukuran yang berbeda yaitu dengan cara menghitung dan membandingkan rasio-rasio keuangan. Dimana rasio-rasio tersebut merupakan cara untuk membandingkan dan menyelidiki hubungan yang ada diantara berbagai bagian informasi keuangan. (Ferdiansyah, 2013).

Penelitian terhadap analisa laporan keuangan yang dikemukakan Riana Febriyanti (2012) dengan judul : "Pengaruh Perputaran Modal Kerja Dan Rasio Hutang Terhadap Profitabilitas Pada PT. Jasa Asuransi Indonesia (Persero)", yang menghasilkan Perputaran Modal Kerja pada PT. Jasa Asuransi Indonesia (Persero), mengalami penurunan dan kenaikan yang cukup signifikan.

Dari penelitian diatas maka dapat disimpulkan pertumbuhan ekonomi pada pasar modal bisa diukur dengan menggunakan beberapa penggolongan rasio yang didasarkan pada dua kelompok, yaitu pertama didasarkan pada sumber datanya menurut Riyanto (2010:30) terdiri dari rasio neraca, rasio laporan laba rugi, dan rasio antar laporan. Kedua didasarkan atas tujuan penganalisa menurut Munawir (2010:69) terdiri dari rasio modal kerja atau likuiditas, rasio solvabilitas, dan rasio rentabilitas atau profitabilitas.

Rasio Likuiditas adalah rasio yang menunjukkan kemampuan suatu perusahaan untuk memenuhi kewajiban keuangan yang harus segera dipenuhi, atau kemampuan perusahaan untuk memenuhi kewajiban pada saat ditagih (Munawir, 2010:37). Pada perusahaan manufaktur menunjukkan likuiditas masih terbilang rendah, karena kondisi ekonomi global yang belum sepenuhnya pulih ditahun 2016, cukup berpengaruh terhadap pertumbuhan industri jamu di Indonesia. Industri jamu diproyeksikan hanya mengalami pertumbuhan sekitar Rp. 3 triliun. Sampai akhir tahun 2016 nanti, industri jamu tanah air diproyeksikan omzetnya berkisar Rp. 20 triliun. Jumlah tersebut tumbuh tipis dibanding pencapaian tahun lalu yang sebesar Rp. 17 triliun. (Wardoyo, 2016). Berkaitan dengan hal tersebut diatas, ada sejumlah hal yang memicu rendahnya likuiditas. Pertama soal literasi masyarakat atas produk industri kecantikan dan kesehatan khususnya perusahaan manufaktur. Kedua kualitas produk, kadang kualitas produk yang tercatat di penjualan perseroan tidak sesuai dengan kondisi rill. Sehingga, ketika ada investor masuk mereka kesulitan untuk menjualnya kembali. (Meilina, 2016).

Selain rasio likuiditas, menurut Riyanto rasio solvabilitas juga perlu diperhitungkan. Pengertian rasio solvabilitas adalah rasio yang menunjukkan kemampuan perusahaan untuk 
memenuhi segala kewajiban financialnya apabila sekiranya perusahaan tersebut akan dilikuidasikan (Riyanto, 2010:32).

Solvabilitas yang terjadi pada PT. Sido Muncul sudah berlangsung lama sejak awal tahun 2015, dimana laba perusahaan belum membaik sepenuhnya hingga tahun 2016. Memburuknya solvabilitas pada PT. Sido Muncul disebabkan oleh pengelolahan perusahaan yang tidak dilakukan secara profesional. (Hadad, 2015). Penjualan produk industri kesehatan dan kecantikan cenderung merugi dan terjadi inefisiensi. Dan tercatat penjualan perseroan mengalami kenaikan sebelumnya Rp.1.119 triliun pada Juni 2014, menjadi Rp.1.141 triliun periode yang sama di tahun 2015 (Djaelani, 2015).

Selain rasio likuiditas dan solvabilitas, menurut Riyanto (2010:32) rasio rentabilitas juga perlu diperhitungkan. Bahwa rasio rentabilitas suatu perusahaan menunjukkan perbandingan antara laba dengan aktiva atau modal yang menghasilkan laba tersebut. Selanjutnya Munawir (2010:33), menyatakan bahwa rentabilitas adalah kemampuan perusahaan menghasilkan laba selama periode tertentu. Selain itu definisi rasio rentabilitas menurut Harahap (2010:304), bahwa rasio rentabilitas atau disebut juga profitabilitas menggambarkan kemampuan perusahaan mendapatkan laba melalui semua kemampuan, dan sumber yang ada seperti kegiatan penjualan, kas, modal, jumlah karyawan, jumlah cabang, dan sebagainya.

Transaksi saham pada PT. Industri Jamu dan Farmasi Sido Muncul, Tbk mencapai Rp.6,7 triliun di pasar negosiasi pada perdagangan saham. Harga saham SIDO cenderung stagnan dipasar negosiasi. Kemungkinan transaksi saham SIDO itu mencapai Rp.13,4 triliun. Kenaikan penjualan mendorong laba bersih yang dapat diatribusikan kepada pemilik entitas naik 7,9\% menjadi Rp.351,92 miliar hingga kuartal III 2016 (Hidayat, 2017). Transaksi lain menunjukkan PT.Kalbe Farma dapat dilakukan penyusunan budget kas, diketahui pada tahun 2014, rentabilitas ekonomi naik menjadi $25,84 \%$ dan begitu juga dengan rentabilitas modal sendiri naik menjadi 23,50\%. Budget kas berperan penting dalam menjaga likuiditas dan rentabilitas pada PT. Kalbe Farma, Tbk. Hal tersebut dapat disimpulkan dari terjaganya keadaan likuiditas ditahun 2014, dan meningkatnya rentabilitas ditahun 2014. (Riskia, 2014).

Dari beberapa pendapat diatas tentang analisis likuiditas, solvabilitas, dan rentabilitas pada perusahaan manufaktur di Indonesia, maka peneliti akan membahas permasalahan terhadap likuiditias, solvabilitas, dan rentabilitas pada PT. Martina Berto, Tbk.

PT. Martina Berto, Tbk adalah perusahaan yang bergerak dibidang manufaktur dan industri perdagangan yang mengkombinasikan antara produk kecantikan dan produk obat - obatan tradisional berupa jamu yang dikemas dengan menarik. Kondisi PT. Martina Berto, Tbk yang dilansir pada website www.kontan.co.id Jakarta tahun 2017 bahwa PT. Martina Berto, Tbk telah mentargetkan pertumbuhan laba bersih 20\% sepanjang tahun 2017. Bagi produsen kosmetika Sariayu Martha Tilaar itu, target yang dirancangkan itu termasuk agresif. Sebab di tahun 2015 lalu bottom line mereka merah. Tahun 2015, Martina Berto mencatatkan rugi bersih sebesar Rp.14,06 miliar. Padahal pendapatan bersih mereka masih tumbuh 3,48\% menjadi Rp.694,78 miliar. Mengintip laporan keuangan terakhir yang terjadi sering dengan peningkatan penjualan bersih, membikin bottom line Martina Berto menguat. Pada kuartal III tahun lalu, laba bersih mereka meningkat lebih dari tiga kali lipat menjadi Rp.8,7 miliar. Cara yang akan ditempuh adalah dengan menekan beban pokok penjualan. Makanya, Martina Berto akan menyisir pengeluaran yang tak efektif. Mulai dari segi financial cost, marketing sales expense, maupun sumber daya manusia. (David, 2016).

Berdasarkan penjelaskan diatas maka tujuan penulis ingin mengnalisis Rasio Likuiditas, Solvabilitas, dan Rentabilitas Dalam Laporan Keuangan Perusahaan Periode 2012-2015 Pada PT. Martina Berto, Tbk".

\section{KAJIAN LITERATUR \\ Analisa Rasio Keuangan}

Menurut Gumanti (2011:111) analisis rasio keuangan adalah : "Salah satu metode yang paling sering digunakan untuk menganalisis prestasi usaha suatu perusahaan. Analisis 
didasarkan pada data-data historis yang tersaji dalam laporan keuangan, baik neraca, laporan laba-rugi, maupun laporan arus kas."

\section{Macam - Macam Analisa Rasio Keuangan \\ Rasio Likuiditas}

Rasio likuiditas adalah rasio yang menunjukkan kemampuan suatu perusahaan untuk memenuhi kewajiban keuangan yang harus segera dipenuhi, atau kemampuan perusahaan untuk memenuhi kewajiban pada saat ditagih (Munawir, 2010:37). Menurut Prastowo (2011:83) rasio likuiditas perusahaan menggambarkan kemampuan perusahaan dalam memenuhi kewajiban jangka pendeknya kepada kreditor jangka pendek". Selain itu definisi likuiditas menurut Kasmir (2012:129), menyatakan bahwa likuiditas berfungsi untuk menunjukkan atau mengukur kemampuan perusahaan dalam memenuhi kewajiban yang sudah jatuh tempo, baik kewajiban kepada pihak luar maupun didalam perusahaan.

Berdasarkan pendapat diatas menurut (Munawir,2010:37 ; Prastowo,2011:83 ; Kasmir,2012:129), maka likuiditas adalah rasio untuk mengukur kemampuan perusahaan untuk memenuhi kewajiban jangka pendek kepada kreditur yang harus segera dipenuhi. Dalam penelitian ini, penilaian terhadap rasio likuiditas didasarkan pada tiga rasio, yaitu antara lain :

a. Current Ratio

Ialah perbandingan antara aktiva lancar dengan hutang lancar. Rasio ini menunjukkan bahwa nilai kekayaan lancar ( yang segera dapat dijadikan uang ) ada sekian kalinya hutang (Munawir, 2010:37).

Secara sistematis dapat dirumuskan :

Current Ratio $=\frac{\text { Aktiva Lancar }}{\text { Hutang Lancar }} \times 100 \%$

Current ratio menunjukkan tingkat keamanan (margin of safety) kreditor jangka pendek atau kemampuan perusahaan untuk membayar hutang - hutangnya yang jatuh tempo. Tetapi current ratio yang tinggi belum tentu menjamin akan dapat dibayarkannya hutang - hutang tersebut, mengingat komposisi dari aktiva lancar itu sendiri. Untuk itu terdapat ratio likuiditas lain yang lebih aman, yaitu quick ratio.

b. Quick Ratio

Ialah perbandingann antara aktiva lancar dikurangi oleh persediaan dan dibagi dengan hutang lancar. Ratio ini merupakan ukuran kemampua perusahaan dalam memenuhi hutang hutangnya dengan tidak memperhitungkan persediaan (Munawir, 2010:37). Dan beranggapan bahwa persediaan mempunyai waktu yang lebih lama untuk dijadikan uang kas. Apabila menggunakan quick ratio untuk menentukan tingkat likuiditas, maka secara umum dapatlah dikatakan bahwa suatu perusahaan yang mempunyai quick ratio kurang dari 1:1 atau 100\% dianggap kurang baik tingkat likuiditasnya (Munawir,2010:37).

Secara sistematis dapat dirumuskan :

$$
\text { Quick Ratio }=\frac{\text { Aktiva Lancar }- \text { Persediaan }}{\text { Hutang Lancar }} \times 100 \%
$$

\section{c. Cash to Current Liabilities Ratio}

Menurut Munawir (2010:38) ialah perbandingan antara kas dengan hutang lancar. Rasio ini menunjukkan seberapa besar kemampuan perusahaan melunasi utang lancarnya dengan menggunakan kas atau setara dengan kas yang dimilikinya. Rata-rata industry untuk cash ratio adalah 50\%, apabila cash ratio kurang dari rata-rata industri kondisi perusahaan kurang baik karena untuk membayar kewajiban masih memerlukan waktu untuk menjual sebagian dari aktiva lancar lainnya.

Secara sistematis dapat dirumuskan :

$$
\text { Cash Ratio }=\frac{\text { Kas }}{\text { Hutang Lancar }} \times 100 \%
$$




\section{Rasio Solvabilitas}

Pengertian dari rasio solvabilitas adalah rasio yang menunjukkan kemampuan perusahaan untuk memenuhi segala kewajiban financialnya apabila sekiranya perusahaan tersebut akan dilikuidasikan (Riyanto, 2010:32). Menurut Munawir (2010:37) ialah angka - angka rasio yang digunakan untuk mengukur tingkat kemampuan perusahaan untuk memenuhi seluruh kewajiban keuangannya apabila perusahaan tersebut dilikuidasi. Selain itu menurut Prastowo (2011:83) menyatakan bahwa solvabilitas menggambarkan suatu perusahaan dalam memenuhi jangka panjangnya. Rasio ini dapat dihitung dari pos-pos yang sifatnya jangka panjang seperti aktiva tetap dan utang jangka panjang.

Berdasarkan pendapat diatas menurut (Riyanto,2010:32 ; Munawir,2010:37 ; Prastowo,2011:83), maka solvabilitas adalah rasio untuk mengetahui dapat atau tidaknya suatu perusahaan dalam memenuhi semua kewajiban jangka panjang pada saat perusahaan dilikuidasi. Dalam penelitian ini, penilaian rasio solvabilitas didasarkan pada 2 Ratio, yaitu antara lain :

a. Total Asset to Debt Ratio

Adalah perbandingan antara total aktiva dengan total hutang, baik jangka pendek maupun jangka panjang. Semakin tinggi rasio ini berarti semakin besar modal pinjaman (utang) yang digunakan dalam menghasilkan keuntungan dibandingkan aktiva yang dimiliki (Riyanto, 2010:32).

Secara sistematis dapat dirumuskan :

$$
\text { Total Asset to Debt Ratio }=\frac{\text { Total Aktiva }}{\text { Total Hutang }} \times 100 \%
$$

Apabila Total Asset to Debt Ratio 100\%, ini berarti jumlah kekayaan sama besarnya dengan jumlah utangnya, sehingga perusahaan tidak memiliki kelebihan aktiva diatas utangnya. Perusahaan harus menggunakan Total Asset to Debt Ratio lebih dari 100\%, supaya bisa dinyatakan baik (Riyanto, 2010:32).

b. Net Worth to Debt Ratio

Adalah perbandingan antara modal sendiri dengan jumlah hutang yang dimiliki perusahaan (Riyanto, 2010:32).

Secara sistematis dapat dirumuskan :

$$
\text { Net Worth to Debt Ratio }=\frac{\text { Modal sendiri }}{\text { Total hutang }} \times 100 \%
$$

Penilaian Net Worth to Debt Ratio rasionya 1:2. Makin kecil presentase ini berarti makin cepat makin cepat insolvabel, karena dengan adanya pengurangan yang kecil saja dari nilai aktivanya, perusahaan sudah dalam keadaan insolvabel (Riyanto, 2010:32).

\section{Rasio Rentabilitas}

Rentabilitas adalah kemampuan perusahaan untuk menghasilkan laba selama periode tertentu (Munawir, $2010: 37$ ).

Menurut Riyanto, (2011:59) menyatakan bahwa rentabilitas suatu perusahaan menunjukkan perbandingan antara laba dengan aktiva atau modal yang menghasilkan laba tersebut. Selain itu rasio rentabilitas atau disebut juga profitabilitas menggambarkan kemampuan perusahaan mendapatkan laba melalui semua kemampuan, dan sumber yang ada seperti kegiatan penjualan, kas, modal, jumlah karyawan, jumlah cabang, dan sebagainya (Harahap, 2010: 304).

Berdasarkan pendapat diatas menurut (Munawir,2010:37 ; Riyanto,2011:59 ; Harahap,2010:304), dapat disimpulkan bahwa rasio ini dimaksudkan untuk mengetahui tingkat laba yang dihasilkan dengan membandingkannya dengan modal atau aktiva yang digunakan dalam menghasilkan laba tersebut. Rentabilitas sering digunakan untuk mengukur efesiensi penggunaan modal dalam suatu perusahaan dengan membandingkan antara laba dengan modal yang digunakan dalam operasi. Oleh karena itu bagi manajemen atau pihak-pihak lain, rentabilitas yang tinggi lebih penting dari pada keuntungan besar. 
Dalam penelitian ini, penilaian rasio rentabilitas ada 2 cara, yaitu antara lain :

a. Rentabilitas Ekonomi

Adalah perbandingan antara laba usaha dengan modal sendiri dan modal asing yang dipergunakan untuk menghasilkan laba tersebut dan dinyatakan dalam persentase. Pengertian rentabilitas ekonomi sering dipergunakan untuk mengukur efisiensi penggunaan modal didalam suatu perusahaan, maka rentabilitas ekonomi sering pula dimaksudkan sebagai kemampuan suatu perusahaan dengan modal yang bekerja didalamnya untuk menghasilkan laba (Riyanto, 2011:59).

Secara sistematis dapat dirumuskan :

Rentabilitas ekonomi $=\frac{\text { Laba Usaha }}{\text { Modal sendiri }+ \text { Modal asing }} \times 100 \%$

\section{b. Rentabilitas Modal Sendiri}

Rentabilitas modal sendiri atau sering disebut juga dinamakan rentabilitas usaha adalah perbandingan antara jumlah laba yang tersedia bagi pemilik modal sendiri atau di satu pihak dengan jumlah modal sendiri yang menghasilkan laba tersebut dilain pihak (Riyanto, 2011:59). Laba yang digunakan dalam menilai rentabilitas modal sendiri adalah laba setelah dikurangi pajak dan bunga atau biasa disebut laba bersih setelah pajak, sedangkan modal yang dipakai dalam perhitungan ini adalah modal sendiri yang ditanamkan dalam perusahaan.

Secara sistematis dapat dirumuskan :

$$
\text { Rentabilas modal sendiri }=\frac{\text { Laba sesudah pajak }}{\text { Modal sendiri }} \times 100 \%
$$

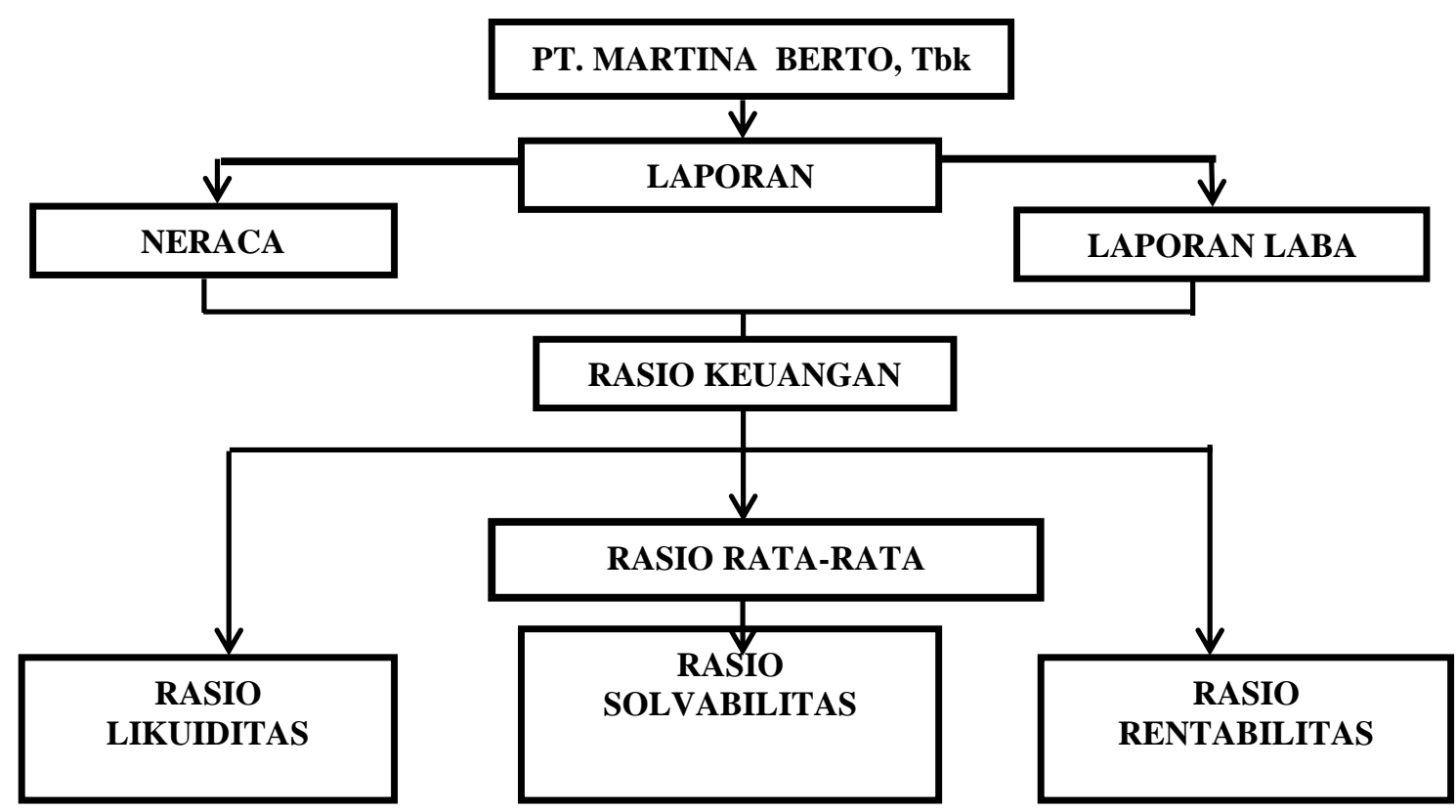

\section{Gambar 2 Kerangka Pikir}

\section{METODE PENELITIAN}

Mengadakan analisi rasio keuangan merupakan dasar untuk mengetahui sejauhmana perusahaan mengalami kemajuan serta menginterprestasikan kondisi keuangan dan hasil 
operasi suatu perusahaan. Data yang digunakan penulis adalah data finansial tahunan yaitu, neraca, laporan laba rugi, laporan perubahan ekuitas dalam beberapa periode berturut - turut yaitu tahun 2012 dan 2015.

\section{PEMBAHASAN}

\section{Analisis Rasio Likuiditas}

Rasio yang menunjukkan kemampuan perusahaan untuk memenuhi kewajiban hutang lancarnya yang harus segera dipenuhi. Dapat dikatakan baik apabila perusahaan membayar hutang tepat pada waktunya dan lancar dalam menjalankan kegiatannya (Munawir, 2010:37).

Rasio - rasio yang digunakan adalah :

a. Current Ratio yaitu kemampuan perusahaan untuk membayar hutang lancar yang harus segera dipenuhi dengan aktiva lancar yang tersedia (Munawir, 2010:37).

$$
\begin{aligned}
& \mathrm{CR}=\frac{\text { Aktiva Lancar }}{\text { Hutang Lancar }} \times 100 \% \\
& \text { CR tahun 2012 }=\frac{510.202 .547 .117}{137.512 .965 .804} \times 100 \% \\
& =371,02 \% \\
& \text { CR tahun } 2013=\frac{453.760 .675 .834}{113.684 .498 .431} \times 100 \% \\
& =399,14 \% \\
& \text { CR tahun } 2014=\frac{442.121 .631 .299}{111.683 .722 .179} \times 100 \% \\
& =395,87 \% \\
& \text { CR tahun } 2015=\frac{467.304 .062 .732}{149.060 .988 .246} \times 100 \% \\
& =313,50 \%
\end{aligned}
$$

Hasil perhitungan menunjukkan hasil berfluktuasi dari tahun 2012 sampai tahun 2015. Artinya bahwa setiap hutang lancar sebesar Rp. 1,00 dijamin dengan aktiva lancar sebesar Rp. 3,71 pada tahun 2012, Rp. 3,99 pada tahun 2013, Rp. 3,95 pada tahun 2014 dan sebesar Rp. 3,13 pada tahun 2015 .

Tabel 4.5 CR Tahun 2012 - 2015 PT. Martina Berto,Tbk

\begin{tabular}{|l|l|l|l|}
\hline Tahun & Aktiva Lancar & Hutang Lancar & CR ( \% ) \\
\hline 2012 & 510.202 .547 .117 & 137.512 .965 .804 & $371,02 \%$ \\
2013 & 453.760 .675 .834 & 113.684 .498 .431 & $399,14 \%$ \\
2014 & 442.121 .631 .299 & 111.683 .722 .179 & $395,87 \%$ \\
2015 & 467.304 .062 .732 & 149.060 .988 .246 & $313,50 \%$ \\
\hline
\end{tabular}

Sumber : Laporan Keuangan PT. Martina Berto, Tbk, Jakarta (data diolah)

Dari tabel diatas dapat ditarik kesimpulan bahwa CR mengalami penaikan pada tahun 2013 sebesar 28,12\% dan penurunan pada tahun 2014 sebesar 3,27\% dan pada tahun 2015 sebesar $82,37 \%$ dikarenakan adanya kenaikan pada hutang lancar dari tahun 2014 ke tahun 2015 sebesar $33,47 \%$ yang tidak diimbangi dengan naiknya aktiva lancar dari tahun 2014 ke tahun 2015 yang hanya $5,70 \%$. 
Tabel 4.6 Perbandingan CR dengan Rata-rata industri

\begin{tabular}{|c|c|c|c|}
\hline Tahun & CR PT. Martina & Rata-rata industri & Selisih $+/-$ \\
\hline 2012 & $371 \%$ & $412 \%$ & < dari rata-rata industri \\
2013 & $399 \%$ & $425 \%$ & < dari rata-rata industri \\
2014 & $395 \%$ & $385 \%$ & > dari rata-rata industri \\
2015 & $313 \%$ & $367 \%$ & < dari rata-rata industri \\
\hline
\end{tabular}

Sumber : Laporan Keuangan ICMD (data diolah)

Berdasarkan tabel perbandingan dengan rata-rata industri, maka dapat disimpulkan bahwa PT. Martina berto walaupun nilai current ratio tergolong tinggi yaitu lebih dari $300 \%$ namun jika dibanding dengan rata-rata industri masih dibawah rata-rata industri. Hal ini berarti penjualan PT. Martina Berto masih perlu ditingkatkan sehingga kas dan asset lancer lebih meningkat.

Jadi , kemampuan pada perusahaan PT. Martina Berto, Tbk untuk membayar hutang lancarnya cukup baik, karena rasio yang biasa dipakai oleh beberapa perusahaan sebesar $200 \%$ atau $1: 1$, namun sebaiknya penganalisa juga melihat komposisi daripada aktiva lancar itu sendiri (Munawir, 2010:37).

b. Quick Ratio yaitu kemampuan perusahaan dalam memenuhi kewajiban - kewajibannya dengan tidak memperhitungkan persediaan (Munawir, 2010:37).

$\mathrm{QR}=\frac{\text { Aktiva Lancar }- \text { Persediaan }}{\text { Hutang Lancar }} \times 100 \%$

$$
\begin{aligned}
\text { QR } 2012 & =\frac{510.202 .547 .117-52.887 .056 .801}{137.512 .965 .804} \times 100 \% \\
& =332,56 \% \\
\text { QR } 2013 & =\frac{453.760 .675 .834-53.263 .258 .533}{113.684 .498 .431} \times 100 \% \\
& =352,29 \% \\
\text { QR } 2014 & =\frac{442.121 .631 .299-74.985 .171 .053}{111.683 .722 .179} \times 100 \% \\
& =328,73 \% \\
\text { QR 2015 } & =\frac{467.304 .062 .732-76.682 .141 .187}{149.060 .988 .246} \times 100 \% \\
& =262,06 \%
\end{aligned}
$$

Hasil perhitungan menunjukkan hasil berfluktuasi, Artinya bahwa setiap Rp. 1,00 hutang lancar dijamin oleh aktiva lancar tanpa persediaan sebesar Rp. 3,32 pada tahun 2012, Rp. 3,52 pada tahun 2013, Rp. 3,28 pada tahun 2014 dan sebesar Rp. 2,62 pada tahun 2015. Itu artinya bahwa perusahaan akan dapat memenuhi kewajibannya tanpa harus menjual persediaan.

Tabel 4.7 QR Tahun 2012 - 2015 PT. Martina Berto,Tbk

\begin{tabular}{|l|l|l|l|l|}
\hline Tahun & Aktiva Lancar & Persediaan & Hutang Lancar & QR (\%) \\
\hline 2012 & 510.202 .547 .117 & 52.887 .056 .801 & 137.512 .965 .804 & $332,56 \%$ \\
2013 & 453.760 .675 .834 & 53.263 .258 .533 & 113.684 .498 .431 & $352,29 \%$ \\
2014 & 442.121 .631 .299 & 74.985 .171 .053 & 111.683 .722 .179 & $328,73 \%$ \\
2015 & 467.304 .062 .732 & 76.682 .141 .187 & 149.060 .988 .246 & $262,06 \%$ \\
\hline
\end{tabular}

Sumber : Laporan Keuangan PT. Martina Berto, Tbk, Jakarta (data diolah) 
Dari tabel perhitungan diatas dapat ditarik kesimpulan bahwa QR mengalami penaikan pada tahun 2013 sebesar 19,73\% dan penurunan pada tahun 2014 sebesar 23,56\% dan pada tahun 2015 sebesar 66,67\% dikarenakan adanya kenaikan pada hutang lancar dari tahun 2014 ke tahun 2015 sebesar 33,47\% yang tidak diimbangi dengan naiknya aktiva lancar dari tahun 2014 ke tahun 2015 yang hanya 5,70\% dan naiknya persediaan dari tahun 2014 ke tahun 2015 sebesar $2,26 \%$. Hal ini dapat dikarenakan nilai persediaan yang masih tinggi, sebab persediaan membutuhkan waktu relative lama untuk direalisir menjadi uang kas.

Tabel 4.8 Perbandingan QR dengan Rata-rata industri

\begin{tabular}{|c|c|c|c|}
\hline Tahun & QR PT. Martina & Rata-rata industri & Selisih $+/$ - \\
\hline 2012 & $332 \%$ & $363 \%$ & < dari rata-rata industri \\
2013 & $352 \%$ & $369 \%$ & < dari rata-rata industri \\
2014 & $328 \%$ & $344 \%$ & < dari rata-rata industri \\
2015 & $262 \%$ & $315 \%$ & < dari rata-rata industri \\
\hline
\end{tabular}

Sumber : Laporan Keuangan ICMD (data diolah)

Berdasarkan tabel perbandingan dengan rata-rata industri, maka dapat disimpulkan bahwa PT. Martina berto walaupun nilai Quick ratio tergolong tinggi yaitu lebih dari $300 \%$ namun jika dibanding dengan rata-rata industri masih dibawah rata-rata industri. Hal ini berarti penjualan PT. Martina Berto masih perlu ditingkatkan sehingga kas dan asset lancer lebih meningkat.

Jadi , kemampuan pada perusahaan PT. Martina Berto, Tbk untuk membayar hutang lancarnya cukup baik dan berada diatas titik aman, karena rasio yang biasa dipakai oleh beberapa perusahaan sebesar $100 \%$ atau $1: 1$, yang berarti bahwa perusahaan pada tahun- tahun tersebut mempunyai aktiva lancar yang sangat likuid yang dapat segera dicairkan untuk membayar kewajiban - kewajibannya (Munawir, 2010:37).

a. Cash to Current Liabilities Ratio, yaitu kemampuan perusahaan untuk membiayai kewajiban jangka pendek dengan uang tunai sebagai sumber utama (Munawir, 2010:38).

$$
\mathrm{CCL}=\frac{\text { Kas }}{\text { Hutang Lancar }} \times 100 \%
$$

$$
\begin{aligned}
\mathrm{CCL} \text { tahun } 2012= & \frac{119.507 .444 .101}{137.512 .965 .804} \times 100 \% \\
& =86,91 \% \\
\mathrm{CCL} \text { tahun } 2013= & \frac{47.589 .357 .527}{113.684 .498 .431} \times 100 \% \\
& =41,86 \% \\
\mathrm{CCL} \text { tahun } 2014= & \frac{41.256 .538 .369}{111.683 .722 .179} \times 100 \% \\
& =36,94 \% \\
\mathrm{CCL} \text { tahun } 2015= & \frac{30.922 .884 .864}{149.060 .988 .246} \times 100 \% \\
& =20,79 \%
\end{aligned}
$$

Hasil perhitungan menunjukkan hasil menurun, Artinya untuk Rp. 1,00 hutang lancar dijamin oleh uang kas sebesar Rp. 0,86 pada tahun 2012, Rp. 0,41 pada tahun 2013, Rp. 0,36 pada tahun 2014 dan sebesar Rp. 0,20 pada tahun 2015.

Tabel 4.9 CCL Tahun 2012 - 2015 PT. Martina Berto,Tbk

\begin{tabular}{|l|l|l|l|}
\hline Tahun & Kas & Hutang Lancar & CR ( \% ) \\
\hline 2012 & 119.507 .444 .101 & 137.512 .965 .804 & $86,91 \%$ \\
\hline
\end{tabular}




\begin{tabular}{|l|l|l|l|}
\hline 2013 & 47.589 .357 .527 & 113.684 .498 .431 & $41,86 \%$ \\
2014 & 41.256 .538 .369 & 111.683 .722 .179 & $36,94 \%$ \\
2015 & 30.922 .884 .864 & 149.060 .988 .246 & $20,79 \%$ \\
\hline
\end{tabular}

Sumber : Laporan Keuangan PT. Martina Berto, Tbk, Jakarta (data diolah)

Dari tabel perhitungan diatas dapat ditarik kesimpulan bahwa CCL mengalami penurunan dari tahun 2013 sampai tahun 2015, pada tahun 2013 sebesar 45,05\% , penurunan pada tahun 2014 sebesar 4,92\% dan pada tahun 2015 sebesar 16,15\% dikarenakan adanya penurunan pada kas dari tahun 2014 ke tahun 2015 yang drastis dan tidak diimbangi dengan naiknya pada hutang lancar dari tahun 2014 ke tahun 2015 sebesar 33,47\%. Dalam suatu perusahaan, kas merupakan alat likuid yang paling dipercaya karena uang tunai yang tersedia langsung dapat dipergunakan untuk membayar semua kewajiban.

Tabel 4.10 Perbandingan CCL dengan Rata-rata industri

\begin{tabular}{|c|c|c|c|}
\hline Tahun & CCL PT. Martina & Rata-rata industri & Selisih + / - \\
\hline 2012 & $86,91 \%$ & $63 \%$ & > dari rata-rata industri \\
2013 & $41,86 \%$ & $59 \%$ & < dari rata-rata industri \\
2014 & $36,94 \%$ & $44 \%$ & < dari rata-rata industri \\
2015 & $20,79 \%$ & $41 \%$ & < dari rata-rata industri \\
\hline
\end{tabular}

Sumber : Laporan Keuangan ICMD (data diolah)

Berdasarkan tabel perbandingan dengan rata-rata industri, maka dapat disimpulkan bahwa PT. Martina berto walaupun nilai cash to Current leabilities ( CCL ) tergolong tinggi yaitu lebih dari $40 \%$ namun jika dibanding dengan rata-rata industri masih dibawah rata-rata industri. Hal ini berarti penjualan PT. Martina Berto masih perlu ditingkatkan sehingga kas dan asset lancer lebih meningkat.

Jadi, kemampuan pada perusahaan PT. Martina Berto, Tbk untuk membayar hutang lancarnya kurang baik dan berada dibawah titik aman, karena rasio yang biasa dipakai oleh beberapa perusahaan sebesar 100\% atau 1: 1, yang berarti bahwa perusahaan tidak dapat melunasi kewajiban hutang-hutangnya dengan uang kas yang dimiliki oleh perusahaan (Munawir, 2010:38).

\section{Solvabilitas}

Rasio yang menunjukkan kemampuan perusahaan untuk memenuhi kewajiban keuangannya apabila perusahaan tersebut dilikuidasi atau dibubarkan, baik kewajiban jangka pendek maupun kewajiban jangka panjang (Riyanto, 2010:32).

Rasio- rasio yang digunakan :

a. Total Asset to Debt Ratio

Rasio ini menunjukkan kemampuan perusahaan dalam membayar kewajibannya dengan menjamin dari seluruh aktiva yang dimiliki perusahaan (Riyanto, 2010:32).

Total Asset to Debt Ratio $=\frac{\text { Total aktiva }}{\text { Total hutang }} \times 100 \%$

$$
\begin{aligned}
& \text { Total Asset to Debt Ratio }=\frac{609.494 .013 .942}{174.931 .100 .594} \times 100 \% \\
& =348,42 \%
\end{aligned}
$$

Tahun 2013 


$$
\begin{aligned}
& =381,28 \% \\
& \text { Total Asset to Debt Ratio }=\frac{623.002 .100 .394}{180.110 .021 .474} \times 100 \% \\
& \text { Tahun } 2014 \\
& =345,90 \%
\end{aligned}
$$$$
\text { Total Asset to Debt Ratio }=\frac{648.899 .377 .240}{214.685 .781 .274} \times 100 \%
$$$$
\text { Tahun } 2015
$$

$$
=302,26 \%
$$

Hasil perhitungan Rasio Total Aktiva dengan Total Hutang menunjukkan hasil berfluktuasi dari tahun 2012 sampai 2015. Artinya bahwa setiap hutang lancar sebesar Rp. 1,00 dijamin dengan aktiva lancar sebesar Rp. 3,48 pada tahun 2012, Rp. 3,81 pada tahun 2013 , Rp. 3,45 pada tahun 2014 dan sebesar Rp. 3,02 pada tahun 2015. Yaitu sebesar 348,42\% pada tahun 2012 dan 381,28\% pada tahun 2013 atau menaik sebesar 32,86\% sedangkan pada tahun 2014 sebesar 345,90 dan sebesar 302,26\% pada tahun 2015 atau menurun sebesar 43,64\%.

Tabel 4.11 Total Asset to Debt Ratio

Tahun 2012 - 2015 PT. Martina Berto,Tbk

\begin{tabular}{|l|r|l|l|}
\hline \multicolumn{1}{|c|}{ Tahun } & Total Aktiva & Total Hutang & $\begin{array}{c}\text { Total Asset to Debt } \\
\text { Ratio (\%) }\end{array}$ \\
\hline 2012 & 609.494 .013 .942 & 174.931 .100 .594 & $348,42 \%$ \\
2013 & 611.769 .745 .328 & 160.451 .280 .610 & $381,28 \%$ \\
2014 & 623.002 .100 .394 & 180.110 .021 .474 & $345,90 \%$ \\
2015 & 648.899 .377 .240 & 214.685 .781 .274 & $302,26 \%$ \\
\hline
\end{tabular}

Sumber : Laporan Keuangan PT. Martina Berto, Tbk, Jakarta (data diolah)

Tabel 4.12 Perbandingan TADR dengan Rata-rata industri

\begin{tabular}{|c|c|c|c|}
\hline Tahun & $\begin{array}{c}\text { TADR } \\
\text { PT. Martina }\end{array}$ & Rata-rata industri & Selisih $+/-$ \\
\hline 2012 & $348,42 \%$ & $283 \%$ & > dari rata-rata industri \\
2013 & $381,28 \%$ & $299 \%$ & $>$ dari rata-rata industri \\
2014 & $345,90 \%$ & $274 \%$ & > dari rata-rata industri \\
2015 & $302,26 \%$ & $269 \%$ & > dari rata-rata industri \\
\hline
\end{tabular}

Sumber : Laporan Keuangan ICMD (data diolah)

Berdasarkan tabel perbandingan dengan rata-rata industri, maka dapat disimpulkan bahwa PT. Martina berto pada nilai Total Asset to Debt Ratio

( TADR ) tergolong tinggi yaitu lebih dari $300 \%$ namun jika dibanding dengan rata-rata industri tetap masih diatas rata-rata industri. Hal ini berarti penjualan PT. Martina Berto lebih baik sehingga kas dan asset lancer sangat meningkat.

Jadi, kemampuan perusahaan PT. Martina Berto, Tbk pada data tabel diatas, untuk membayar hutang lancarnya cukup baik dan berada diatas titik aman, karena rasio yang biasa dipakai oleh beberapa perusahaan sebesaar $100 \%$ atau $1: 1$, meski pada tahun 2014 dan 2015 mengalami sedikit penurunan akibat dari naiknya total hutang, namun perusahaan masih dalam keadaan baik atau solvabel (Riyanto, 2010:32).

b. Net Worth to Debt Ratio

Rasio ini menunjukkan sejauhmana peranan modal sendiri terhadap kemampuan perusahaan dalam memenuhi kewajiban - kewajibannya (Riyanto, 2010:32). 


$$
\text { Net Worth to Debt Ratio }=\frac{\text { Modal sendiri }}{\text { Total hutang }} \times 100 \%
$$

$$
\text { Net Worth to Debt Ratio }=\frac{107.000 .000 .000}{174.931 .100 .594} \times 100 \%
$$

Tahun 2012

$$
\begin{aligned}
& =61,17 \% \\
\text { Net Worth to Debt Ratio } & =\frac{107.000 .000 .000}{160.451 .280 .610} \times 100 \%
\end{aligned}
$$

Tahun 2013

$$
=66,69 \%
$$

Net Worth to Debt Ratio

$$
=\frac{107.000 .000 .000}{180.110 .021 .474} \times 100 \%
$$

Tahun 2014

$$
=59,41 \%
$$$$
\text { Net Worth to Debt Rati }=\frac{107.000 .000 .000}{214.685 .781 .274} \times 100 \%
$$

Tahun 2015

$$
=49,84 \%
$$

Hasil perhitungan menunjukkan nilai Rasio Modal dengan Total Hutang pada PT. Martina Berto, Tbk menunjukkan hasil yang berfluktuasi dari tahun 2012 sampai 2015. Artinya bahwa total hutang perusahaan sebesar Rp. 1,00 dijamin dengan modal sendiri sebesar Rp. 0,61 pada tahun 2012, Rp. 0,66 pada tahun 2013 , Rp. 0,59 pada tahun 2014 dan sebesar Rp. 0,49 pada tahun 2015. Rasio Modal dengan Total Hutang pada tahun 2012 sebesar 61,17\%, sedangkan pada tahun 2013 sebesar $66,69 \%$ atau meningkat sebesar 5,52\% dan pada tahun 2014 dengan nilai $59,41 \%$ atau menurun sebesar 7,28\% dan menurun kembali di tahun 2015 dengan nilai $49,84 \%$ atau sebesar $9,57 \%$.

Tabel 4.13 Net Worth to Debt Ratio Tahun 2012 - 2015 PT. Martina Berto,Tbk

\begin{tabular}{|l|l|r|l|}
\hline \multicolumn{1}{|c|}{ Tahun } & \multicolumn{1}{c|}{ Modal Sendiri } & Total Hutang & $\begin{array}{c}\text { Net Worth to Debt } \\
\text { Ratio }(\%)\end{array}$ \\
\hline 2012 & 107.000 .000 .000 & 174.931 .100 .594 & $61,17 \%$ \\
2013 & 107.000 .000 .000 & 160.451 .280 .610 & $66,69 \%$ \\
2014 & 107.000 .000 .000 & 180.110 .021 .474 & $59,41 \%$ \\
2015 & 107.000 .000 .000 & 214.685 .781 .274 & $49,84 \%$ \\
\hline
\end{tabular}

Sumber : Laporan Keuangan PT. Martina Berto, Tbk, Jakarta (data diolah)

Tabel 4.14 Perbandingan NWDR dengan Rata-rata industri

\begin{tabular}{|c|c|c|c|}
\hline Tahun & CR PT. Martina & Rata-rata industri & Selisih $+/$ - \\
\hline 2012 & $61,17 \%$ & $81 \%$ & $<$ dari rata-rata industri \\
2013 & $66,69 \%$ & $74 \%$ & < dari rata-rata industri \\
2014 & $59,41 \%$ & $72 \%$ & $<$ dari rata-rata industri \\
2015 & $49,84 \%$ & $64 \%$ & < dari rata-rata industri \\
\hline
\end{tabular}

Sumber : Laporan Keuangan ICMD (data diolah)

Berdasarkan tabel perbandingan dengan rata-rata industri, maka dapat disimpulkan bahwa PT. Martina berto walaupun nilai Net Worth to Debt Ratio 


\section{JURNAL AKUNTANSI, Vol. 8, No. 1, April (2019)}

( NWDR ) tergolong tinggi yaitu lebih dari $40 \%$ namun jika dibanding dengan rata-rata industri masih dibawah rata-rata industri. Hal ini berarti penjualan PT. Martina Berto masih perlu ditingkatkan sehingga kas dan asset lancer lebih meningkat.

Jadi, dari perhitungan tabel diatas dapat diketahui bahwa rasio mengalami penurunan dari tahun ke tahun, dan kemampuan perusahaan untuk membayar semua kewajibannya tidak baik dan berada dibawah titik aman yaitu 100\% yang berarti perusahaan tersebut belum dapat memenuhi kewajibannya yang berasal dari modal sendiri (Riyanto, 2010:32). Bila dibandingkan dengan rata-rata industri.

\section{Rasio Rentabilitas}

Menurut Riyanto, (2011:59) adalah rasio yang menunjukkan kemampuan perusahaan untuk menghasilkan laba selama periode tertentu.

Rasio - rasio yang digunakan :

a. Rentabilitas ekonomi

Menunjukkan kemampuan dari laba yang didapatkan dalam modal untuk menghasilkan keuntungan bagi semua investor (Riyanto, 2011:59).

Rentabilitas ekonomi $\quad=\frac{\text { Laba Usaha }}{\text { Modal sendiri }+ \text { Modal asing }} \times 100 \%$

Rentabilitas Ekonomi

tahun 2012

Rentabilitas Ekonomi

tahun 2013

Rentabilitas Ekonomi

tahun 2014

Rentabilitas Ekonomi

tahun 2015

$$
=\frac{54.075 .229 .664}{321.500 .000 .000} \times 100 \%
$$$$
=16,82 \%
$$$$
=\frac{21.535 .002 .432}{321.500 .000 .000} \times 100 \%
$$$$
=6,70 \%
$$

$$
=\frac{9.657 .624 .034}{321.500 .000 .000} \times 100 \%
$$

$$
\begin{aligned}
& =3,00 \% \\
& =\frac{-11.454 .570 .311}{321.500 .000 .000} \times 100 \%
\end{aligned}
$$

$$
=-3,56 \%
$$

Hasil perhitungan menunjukkan nilai Rentabilitas Ekonomi menurun sangat drastris pada PT. Martina Berto, Tbk dari tahun 2012 sampai 2015. Artinya bahwa laba yang dihasilkan oleh perusahaan sebesar $16,82 \%$ pada tahun $2012,6,70 \%$ pada tahun $2013,3,00 \%$ pada tahun 2014 , dan $-3,56 \%$ pada tahun 2015 .

Tabel 4.15 Rentabilitas Ekonomis Tahun 2012 - 2015 PT. Martina Berto,Tbk

\begin{tabular}{|l|l|l|l|}
\hline Tahun & \multicolumn{1}{|c|}{ Laba Usaha } & \multicolumn{1}{|c|}{$\begin{array}{c}\text { Modal Sendiri } \\
+ \\
\text { Modal Asing }\end{array}$} & $\begin{array}{c}\text { Rentabilitas Ekonomis } \\
(\%)\end{array}$ \\
\hline 2012 & 54.075 .229 .664 & 321.500 .000 .000 & $16,82 \%$ \\
2013 & 21.535 .002 .432 & 321.500 .000 .000 & $6,70 \%$ \\
2014 & 9.657 .624 .034 & 321.500 .000 .000 & $3,00 \%$ \\
2015 & $(11.454 .570 .311)$ & 321.500 .000 .000 & $-3,56 \%$ \\
\hline
\end{tabular}


Sumber : Laporan Keuangan PT. Martina Berto, Tbk, Jakarta (data diolah)

Dari tabel perhitungan diatas, rentabilitas ekonomis yang diperoleh perusahaan mengalami penurunan setiap tahunnya dari angka $16,82 \%$ menjadi $-3,56 \%$ pada tahun 2012 sampai tahun 2015. Yaitu penurunan sebesar $10,12 \%$ pada tahun 2013 , sebesar $3,70 \%$ penurunan pada tahun 2014, dan sebesar 6,56\% pada tahun 2015. Hal ini dikarenakan ketidakmampuan perusahaan dalam menghasilkan laba yang baik.

Tabel 4.16 Perbandingan RE dengan Rata-rata industri

\begin{tabular}{|c|c|c|c|}
\hline Tahun & RE PT. Martina & Rata-rata industri & Selisih $+/-$ \\
\hline 2012 & $16,82 \%$ & $11 \%$ & > dari rata-rata industri \\
2013 & $6,70 \%$ & $9,6 \%$ & < dari rata-rata industri \\
2014 & $3,00 \%$ & $7,8 \%$ & < dari rata-rata industri \\
2015 & $-3,56 \%$ & $13,2 \%$ & < dari rata-rata industri \\
\hline
\end{tabular}

Sumber : Laporan Keuangan ICMD (data diolah)

Berdasarkan tabel perbandingan dengan rata-rata industri, maka dapat disimpulkan bahwa PT. Martina berto untuk rentabilitas masih kurang baik. Karena dibawah rata-rata industry. Hal ini berarti penjualan PT. Martina Berto masih perlu ditingkatkan sehingga laba usaha lebih meningkat.

Rentabilitas ekonomis dapat dijadikan acuan bagi investor untuk menilai keefektifan operasional perusahaan dalam menghasilkan laba sebelum pajak. Semakin tinggi rentabilitas ekonomis, semakin baik bagi perusahaan. Sebaliknya, jika semakin rendah rentabilitas ekonomisnya maka semakin tidak baik untuk perusahaan (Riyanto, 2011:59).

b. Rentabilitas Modal Sendiri

Menunjukkan kemampuan untuk menghasilkan laba dari modal sendiri yang untuk beroperasi (Riyanto, 2011:59).

Rentabilitas Modal Sendiri $=\frac{\text { Laba sesudah pajak }}{\text { Modal sendiri perusahaan }} \times 100 \%$

Rentabilitas Modal Sendiri $=\frac{45.523 .078 .819}{107.000 .000 .000} \times 100 \%$

tahun 2012

$$
=42,54 \%
$$

Rentabilitas Modal Sendiri $=\frac{16.162 .858 .075}{107.000 .000 .000} \times 100 \%$

tahun 2013

$\begin{aligned} & =15,11 \% \\ \text { Rentabilitas Modal Sendiri }= & \frac{4.209 .673 .280}{107.000 .000 .000} \times 100 \%\end{aligned}$

tahun 2014

$\begin{aligned} & =3,93 \% \\ \text { Rentabilitas Modal Sendiri }= & \frac{-14.056 .549 .894}{107.000 .000 .000} \times 100 \%\end{aligned}$

tahun 2015

$$
=-13,14 \%
$$

Hasil perhitungan menunjukkan nilai Rentabilitas Modal Sendiri menurun sangat drastris pada PT. Martina Berto, Tbk dari tahun 2012 sampai 2015. Artinya bahwa laba yang dihasilkan 
oleh perusahaan sebesar $42,54 \%$ pada tahun $2012,15,11 \%$ pada tahun $2013,3,93 \%$ pada tahun 2014, dan $-13,14 \%$ pada tahun 2015.

Tabel 4.17 Rentabilitas Modal Sendiri

Tahun 2012 - 2015 PT. Martina Berto,Tbk

\begin{tabular}{|l|l|l|l|}
\hline Tahun & \multicolumn{1}{|c|}{$\begin{array}{c}\text { Laba Sesudah } \\
\text { Pajak }\end{array}$} & \multicolumn{1}{|c|}{$\begin{array}{c}\text { Modal } \\
\text { Sendiri }\end{array}$} & \multicolumn{1}{|c|}{$\begin{array}{c}\text { Rentabilitas Modal Sendiri } \\
(\%)\end{array}$} \\
\hline 2012 & 45.523 .078 .819 & 107.000 .000 .000 & $42,54 \%$ \\
2013 & 16.162 .858 .075 & 107.000 .000 .000 & $15,11 \%$ \\
2014 & 4.209 .673 .280 & 107.000 .000 .000 & $3,93 \%$ \\
2015 & $(14.056 .549 .894)$ & 107.000 .000 .000 & $-13,14 \%$ \\
\hline
\end{tabular}

Sumber : Laporan Keuangan PT. Martina Berto, Tbk, Jakarta (data diolah)

Dari tabel perhitungan diatas, rentabilitas modal sendiri yang diperoleh perusahaan mengalami penurunan setiap tahunnya dari angka 42,54\% menjadi $-13,14 \%$ pada tahun 2012 sampai tahun 2015. Yaitu penurunan sebesar 30,43\% pada tahun 2013, sebesar $11,18 \%$ penurunan pada tahun 2014 , dan sebesar $17,07 \%$ pada tahun 2015 . Hal ini dikarenakan ketidakmampuan perusahaan dalam menghasilkan laba yang baikdari modal sendiri yang digunakan untuk operasional.

Tabel 4.18 Perbandingan RS dengan Rata-rata industri

\begin{tabular}{|c|c|c|c|}
\hline Tahun & RS PT. Martina & Rata-rata industri & Selisih + / - \\
\hline 2012 & $42,54 \%$ & $14,7 \%$ & > dari rata-rata industri \\
2013 & $15,11 \%$ & $12,6 \%$ & < dari rata-rata industri \\
2014 & $3,93 \%$ & $11,8 \%$ & < dari rata-rata industri \\
2015 & $-13,14 \%$ & $16 \%$ & < dari rata-rata industri \\
\hline
\end{tabular}

Sumber : Laporan Keuangan ICMD (data diolah)

Berdasarkan tabel perbandingan dengan rata-rata industri, maka dapat disimpulkan bahwa PT. Martina berto untuk rentabilitas ratio laba sesudah pajak dibanding modal sendiri masih sangat rendah terutama untuk Tahun 2014 dan 2015. Hal ini berarti penjualan PT. Martina Berto masih perlu ditingkatkan sehingga penerimaan pendapatan naik dan laba usaha naik dan kondisi ini perlu diperhatikan untuk tidak mengalami kerugian seperti pada Tahun 2015.

\section{PENUTUP}

Berdasarkan hasil penelitian menunjukkan bahwa kinerja keuangan perusahaan PT. Martina Berto, Tbk selama tahun 2012 sampai 2015 secara umum masih dibawah rata-rata industry sehingga perlu menjadi perhatian manajemen. Walaupun secara current ratio dan quick ratio masih tergolong aman namun karena tahun 2015 perusahaan mengalami penurunan laba bersih sehingga membuat kinerja menjadi lebih buruk. Dilihat dari current ratio dan quick ratio yaitu Rasio Likuiditas perusahaan masih berada diatas standar untuk current ratio dan quick ratio, akan tetapi jika dilihat dari cash ratio posisi likuiditas PT. Martina Berto, Tbk menunjukkan kondisi yang kurang baik, karena rasio likuiditas perusahaan berada dibawah standar, hal ini menunjukkan PT. Martina Berto, Tbk tidak mampu untuk membayar hutang jangka pendeknya dengan uang kas perusahaan secara tunai. Jika dilihat rasio total aktiva dengan total hutang menunjukkan keadaan perusahaan yang baik (solvabel) karena rasio ini menunjukkan lebih besar, berarti bahwa aktiva tetap perusahaan mampu untuk memenuhi kewajiban - kewajibannya dan juga perusahaan mampu memperoleh pinjaman baru karena aktiva yang dimiliki oleh perusahaan ini dapat menjamin hutang-hutang jangka panjangnya. Dan jika dilihat dari rasio modal dengan total hutang dan rasio total hutang dengan modal 
sendiri perusahaan berada dalam kondisi kurang sehat. Hal ini menunjukkan bahwa perusahaan akan mengalami kesulitan dalam memenuhi kewajibannya, sebab banyak dari modal itu sendiri yang dijadikan jaminan hutang jangka panjangnya. Dari segi rasio rentabilitas, perusahaan pada tahun - tahun ini kesulitan dalam menghasilkan laba, meskipun jumlah penjualan dan laba yang dihasilkan dari tahun ke tahun naik, hal ini disebakan oleh beberapa faktor antara lain konsentrasi perusahaan terhadap peningkatan kuantitas produksi dan pengembangan dibidang manufaktur.

Berdasarkan hasil analisa laporan keuangan yang telah penulis bahas maka penulis ingin memberikan saran sebagai bahan masukan yang mungkin berguna, antara lain :

1. Untuk meningkatkan kinerja laporan keuangan perusahaan PT. Martina Berto, Tbk sebaiknya memperkecil beban pokok penjualan agar dapat meningkatkan jumlah laba bersih perusahaan, dengan kata lain perusahaan harus menurunkan jumlah pos - pos biaya sehingga perusahaan dapat berada dalam kondisi yang benar - benar sehat.

2. PT. Martina Berto, Tbk sebaiknya meningkatkan jumlah kas / setara kas pada pos aktiva lancar sehingga perusahaan dapat memenuhi kewajiban yang segera jatuh tempo.

3. Terus meningkatkan profesionalisme perusahaan dengan memberikan pelayanan memuaskan kepada customer dan memberikan produk yang lebih berkualitas kepada para konsumen, sehingga customer dan konsumen puas dan tidak lari ke lain produk atau tempat.

4. Akan lebih baik bagi PT. Martina Berto, Tbk apabila melakukan analisa laporan keuangan secara berkala, sehingga perkembangan perusahaan dapat diketahui dan dijadikan sebagai bahan pertimbangan dalam pengambilan keputusan.

\section{REFERENSI}

Agnes, Sawir, 2012, Analisis Kinerja Keuangan dan Perencanaan Keuangan Perusahaan, 1, Jakarta : Gramedia Pustaka Utama

Agus Harjito dan Martono, 2011, Manajemen Keuangan, 50, Edisi Kedua, Yogyakarta : Ekonisia

Any, Fitri , dkk, 2012, Analisis Rasio Likuiditas, Solvabilitas, dan Rentabilitas Dalam Mrnilai Kinerja Keuangan pada Perum Damri Stasiun Samarinda, FEUM : Samarinda

Astuti, Retno Budi dan Murwanti, 2010, Analisis Penilaian Kinerja Keuangan Dengan Menggunakan Pendekatan Rasio (Studi Kasus Pada PT. Unilever Indonesia, Tbk), Jurnal Manajemen dan Bisnis, vol. 1, No.5

Atmajaya, LS, 2009, Teori dan Praktik Manajemen Keuangan, 41, Yogyakarta : Andi

Belkaoui, Ahmed Riahi, 2010, Teori Akuntansi, 125, Edisi Kelima, Jakarta : Salemba Empat

Bernstein, Leopold A, 2011, Analysis of Finance Statements, 21 Revised Edition, New York : Richard D. Irwin. Inc

Departemen Pendidikan Nasional, 2011, Kamus Besar Bahasa Indonesia Pusat Bahasa, Jakarta : PT. Gramedia Pustaka Utama

Dwi, Prastowo, 2011, Analisa Laporan Keuangan Konsep dan Aplikasi, 83, Edisi Ketiga, Yogyakarta : UPP STIM YKPN

David Emil, Bryan, 2016 "Martina Berto Bidik Laba Tumbuh 20\%", http://industri.kontan.co.id/news/Martina-berto-bidik-laba-tumbuh-20.

Djaelani, Firdaus, 2015, “Sido Muncul Cetak Kenaikan Laba Bersih Rp.246,1 Miliar”, Tempo, Jakarta: 30 Juli.

Fahmi, Irham, 2012, Analisa Kinerja Keuangan, 2, Bandung : Alfabeta

Febriyanti, Riana, 2012, Pengaruh Perputaran Modal Kerja Dan Rasio Hutang Terhadap Profitabilitas Pada PT. Jasa Asuransi Indonesia (Persero), UNIKOM : Bandung

Ferdiansyah, Davi, 2013, Likuiditas, Solvabilitas, Aktivitas dan Rentabilitas untuk Mengukur Kinerja Keuangan pada PT. Madu Baru Tahun 2010-2012, Universitas Negeri Yogyakarta : Tidak Diterbitkan 


\section{JURNAL AKUNTANSI, Vol. 8, No. 1, April (2019)}

Garrison, Ray H dan Noreen, 2013, Akuntansi Manajerial, 15, Edisi Keempat Belas, Jakarta : Salemba Empat

Gumanti, Tatang, 2011, Manajemen Investasi Konsep, Teori, dan Aplikasi, 111, Edisi Kesatu, Jakarta : Mitra Wacana Media

Hadad, Muliaman, 2015, “Sido Muncul Cetak Kenaikan Laba Bersih Rp.246,1 Miliar”, Tempo, Jakarta: 30 Juli.

Halim, Abdul dan Mahmud M. Hanafi, 2009, Analisis Laporan Keuangan, 65, 77, 88, Edisi Keempat, Yogyakarta : UPP STIM YKPN

Harahap, Sofyan Safitri, 2010, Analisis Kritis Atas Laporan Keuangan, 257, 259, 270, 271, 304, Edisi Kesebalas, Jakarta : Raja Grafindo Persada

Harrison, Welter, et, al, 2012, Akuntansi Keuangan, 2, Edisi Kedelapan, Jakarta : Erlangga

Hidayat, Irwan, 2017, “Transaksi Saham Sido Muncul Capai Rp. 6,7 Triliun di Pasar Nego", Sindo, Jakarta: 14 Maret.

Ikatan Akuntansi Indonesia, 2015, Standar Akuntansi Keuangan, PSAK No.1, Jakarta : IAI

Irawati, Susan, 2010, Manajemen Keuangan, 22, Bandung : Pustaka

Kamil, Ridwan, 2016, “Ini Hasil Audit Keuangan Kota Bandung Oleh BPK”, Tempo, Jakarta: 7 Juni.

Kartika, Ayu Norma, 2012, Analisis Laporan Keuangan Pada Perusahaan Semen Yang Terdaftar di BEI (Studi Kasus PT. Gresik Persero, PT. Indocement Tunggal Prakarsa, Dan PT. Holcim,Tbk), Universitas Trisakti : Jakarta

Kasmir, 2010, Analisa Laporan Keuangan, 7, Edisi Kesatu, Yogyakarta : Rajawali Pers

Kasmir, 2012, Analisa Laporan Keuangan, 104, 129, Jakarta : PT. Raja Grafindo Persada

Krisantus, 2017, “Analisa Fundamental Saham Indonesia PT.SIDO 2016”, http://analisafundamental-saham.blogspot.co.id/2017/04/sido-pt-industri-jamu-dan-farmasisido.html

Meilina, Susi, 2016, “Likuiditas Transaksi Perseroan Masih Timpang”, http://investasi.kontan.co.id d/news/likuiditas-transaksi-perseroan-masih-timpang.

Munawir, S, 2010, Analisa Laporan Keuangan, 5, 7, 25, 26, 33, 37, 38, 39, 69, Edisi Keempat, Yogyakarta : Liberty

Rahma, Mutiara Nur, 2016, Analisa Laporan Keuangan Dalam Menilai Kinerja Keuangan Industri Semen Yang Terdaftar di BEI (Studi Kasus PT. Indocement Tunggal Prakarsa, Tbk), Jurnal Bina Insani, vol. 1, No. 1

Riskia, Ainur, 2014, Penggunaan Budget Kas Untuk Menjaga Likuiditas Dan Meningkatkan Rentabilitas, Jurnal Administrasi Bisnis, vol. 5, No. 2 (online ProQuest).

Riyanto, Bambang, 2010, Dasar - Dasar Pembelanjaan Perusahaan, 30, 32, 34, 35, 36, 44, Edisi Keempat, Yogyakarta : BPFE

Rodoni, Ahmad, 2010, Manajemen Keuangan, 16, Jakarta : Mitra Wacana Media

Stice dan Skousen, 2009, Akuntansi Intermediate, 18, Edisi Keenam Belas, Jakarta : Salemba Empat

Sutrisno, 2012, Manajemen Keuangan Teori, Konsep dan Aplikasi, 53, Yogyakarta : Ekonisia Syifa, Arman, 2016, “Ini Hasil Audit Keuangan Kota Bandung Oleh BPK”, Tempo, Jakarta: 7 Juni.

Tandelilin, Eduardus, 2010, Portofolio dan Investasi Teori dan Aplikasi, 48, Edisi Pertama, Yogyakarta : Kanisius

Wardoyo, Nyoto, 2016, “Tahun Ini Industri Jamu Tumbuh Melambat”, http://ekbis.sindonews.com/read/1148903/34/tahun-ini-industri-jamu-tumbuhmelambat-1476985648.

www.idx.com

www.martinaberto.com

Yunita, Nova, 2011, Pengaruh EPS, NPM, ROA, ROE, dan DER Terhadap Return Saham Pada Perusahaan Manufaktur Yang Terdaftar di BEI Tahun 2008-2010, Universitas Gajah Mada : Yogyakarta 